\title{
罟 THE DEVELOPMENT OF SERBIAN AVIATION AND AVIATION SIGNAL STATIONS AND THEIR SIGNIFICANCE ON THE SALONICA FRONT
}

\author{
Vitomir A. Stanković \\ University of Defence in Belgrade, School of National Defence
}

The development of human society and human conscience has con-

tributed to the general progress in different spheres. Man, observing the surroundings, has always tended to adjust the environment to his needs. Thus, at one point, looking into the sky, he experienced a desire to fly in the vast space above him and be free like a bird. Such ideas have not just been a dream, but represented a need to test the human capabilities, too. Hence he has started, initially in a primitive way, and later with more sophistication, to contrive mechanisms, which would take him into free and yet unexplored sky. The first balloon flight was performed out in the long gone year of 1783, when the Montgolfier brothers flew over Paris. George Cayley, an English engineer, carried out several flights between 1804 and 1853. He was the first to construct a flying machine with fixed wings and separate systems for take-off, motion and control.

In 1874 Felix du Temple de la Croix, a navy officer, constructed a flying device resembling the wings of a bird, with a wheel retracting into the base, a propeller and a $6 \mathrm{HP}$ motor. Clement Ader, a French engineer, constructed in 1890 a flying device called Eole powered by a steam engine with four cylinders, $20 \mathrm{HP}$ and four propellers. Otto Lilienthal, a German civil engineer, managed to perform the first safe flight in history. His scientific approach was adopted by the Wright brothers. Orville and Wilbur Wright constructed the first "successful" airplane in the world, whose flight on 17 December 1903 was fully controlled. Later on, they developed a fixed airplane wing and introduced electronic adjustments in the airplane.

Key Words: ideas about flying, balloons, controlled flight, airplane with a motor, fixed-wing

\section{Introduction}

$T$ he first ideas and practical attempts to promote aviation in Serbia and to introduce its use in the military were recorded as early as in the middle of the $19^{\text {th }}$ century. Matija Ban's article "Aviation", published in Serbian Newspaper in September 1844 is the first written document about aviation in Serbia. The ideas related to aviation were dis- 
seminated by the Serbian officers and professionals educated in Russia and the West. The first hot - air balloon flew over Belgrade in 1873 whereas over Pančevo in 1880. The balloon was operated by the Frenchman Bede, who toured many European cities, at that time, demonstrating the art of flying a balloon. The introduction of aviation into the Serbian Armed Forces was initiated by King Aleksandar I Obrenović in 1893, via his order to organize within divisions, if possible, "aviation and bicycle units using personnel trained for these activities in the peacetime". At the beginning of the $20^{\text {th }}$ century France, Germany, Russia and Great Britain were the countries that took the lead in the development of aviation, while the Kingdom of Serbia took measures to establish the Air Force. One of the best educated Serbian officers at the time, Miloš Vasić, in the capacity of the Minister of the Military, foreseeing the formation of the Air Force units, decided in 1900 to commence with educating aviation experts, so that a group of officers and non-commissioned officers was sent to attend school abroad.

The creation of the Serbian Air Force at the beginning of the previous century in a small and poor country like the Kingdom of Serbia was conditioned by the danger posed by Austria-Hungary, as well as the Serbian preparations for completing the liberation from the Ottoman Empire. In such international circumstances, despite the harsh economic conditions, Serbia had to equip its military with modern armament. During the opening years of the 20th century, modernization of the outdated armaments began in Serbia, and even the possibility of introducing balloons was considered, following the model of the militaries of larger European states. In February 1901, engineering captain Kosta Miletić was sent to attend school in Russia, thus becoming the first officer trained in handling free and tied balloons, and in pigeon mail organization.

During the annexation crisis, at the end of 1908 and the beginning of 1909, Serbia acquired two balloons. The first six pilots completed training in France before the beginning of the First Balkan War, and the Field Marshal Radomir Putnik signed a document, which established the Air Force Command in Niš. This event entered the history books as the date of the formation of the military aviation of our country. In March of the following year, our airplanes appeared above the besieged Skadar, while sergeant pilot Mihajlo Petrović, in the course of his first combat flight, became the first victim of the Serbian military aviation.

At the onset of World War I, with a small number of airplanes and balloons, the Serbian pilots provided the Supreme Command with valuable information on the movement of the enemy troops, while at the begenning of 1915 they introduced armaments into their planes. Until the Mackensen's offensive Serbian and French pilots maintained dominance in the air and offered valuable data to the Serbian Supreme Command, at the time when the fateful decision on the army's retreat via Albania was made. During the retreat, the French pilots were the first in the world, who transported the sick and the wounded by plane. Together with Serbian pilots, they maintained communication between the parts of the army retreating along the Albanian coast toward Durres and Vlore.

In 1915, the Supreme Command of the Serbian Armed Forces ordered the formation of permanent airplane signal stations with the aim of organizing surveillance of the airspace, thus beginning to extablish the air defence system within the Serbian military. The Serbian aviation and its pilots, aided by the newly established airplane signal stations and their crews, gave immeasurable contribution to the breakthrough at the Salonica Front. Its presence had a special positive effect on the morale of our soldiers and commanding officers. 
After the reorganization on Corfu, the Serbian airmen joined the ranks od five French squadrons, which the Allied conference held in March 1916, allocated as the support to the Serbian Armed Forces in the strategically most important sector of the Salonica Front. The Serbian Supreme Command retained under its control the headquarters of the Serbian airplane squadron and the airplane depot in Mikra, preserving the nucleus of its own nascent aviation. Towards the end of the war, the Serbian squadrons were armed with the most modern airplanes, and together with the allies took initiative, fully demonstrating the power and potential of air dominance, as well as air support to the troops on the ground.

The unstoppable onslaught of the Serbian army pushed the enemy troops about 600 kilometers in just 45 days resulting in liberation of the fatherland. During the preparation for the breakthrough at the Salonica Front, the First and the Second squadrons combined into one squadron of 40 airplanesthat carried out surveillance, made photographic records and bombed the enemy infrastructure. The fighter airplanes safeguarded the activities of the surveillance and bombing aviation and provided air protection to the Serbian forces. About thirty German and Bulgarian airplanes were taken down in the area fights, while the anti-aircraft defence gunned down five airplanes. After the liberation of Skoplje in October 1918, all fighting squadrons, airplane squadrons and airplane depot with the airplane park, were gathered in the mentioned town. Our first airplanes flew over to Niš on 18 October 1918, and they immediately took part in combat missions. In late November and early December 1918 Serbian aircraft flew to Novi Sad via Belgrade.

At the Salonica Front our pilots carried out about 600 combat flights, and witnessed the end of the war operating 60 modern airplanes manned by 70 pilots and over 300 mechanics and other specialists. This formed the basis for creating the military and civil aviation of the new state.

\section{Use of Military Aviation in Our War Theater in the Balkan Wars}

The ideas and practical attempts to introduce aviation in Serbia were documented in the mid- $19^{\text {th }}$ century. The first written document about aviation in Serbia was Matija Ban's article "Aviation", published in Serbian Newspaper in September 1844. In addition to this article and similar writings in newspapers later on, the ideas related to aviation were disseminated by the Serbian officers and professionals educated in Russia and the West. The first hot-air balloon flew above Belgrade in 1873 and above Pančevo in 1880. The balloon was operated by the Frenchman Bede, who toured many European cities, at that time, demonstrating the art of flying a balloon. Nikola Tesla in his projects and patents also paid great attention to conceptual and technical solutions for flying devices. His drawings from 1886 are original documents in which he presented his ideas about aviation. The beginning of the $20^{\text {th }}$ century was marked by the vigorous development of aviation, and the countries which took the lead in that development were: France, Germany, Russia and Great Britain. It took the Kingdom of Serbia more time to establish the Air Force as part of the Serbian military. The introduction of aviation into the Serbian Armed Forces was initiated by King Aleksandar I Obrenović in 1893, via his order to organize within divisions, if possible, "aviation and bicycle units using personnel trained for these activities in the peacetime". Nothing 
concrete was done in the Serbian military at that time, but in the period, which followed, there were numerous thematic articles in the military paper "The Warrior", which has certainly contributed to the introduction of aviation into the Armed Forces soon after.

Along with the establishment of the Serbian state, the Serbian army was created, which was a guarantee of its safety and survival. The military became an organized institution with its internal structure and functional scheme. There was the need for training and professional development, as well as the need for new equipment and armament. The division into regular and standing armed forces was implemented, ranks were introduced and leading officers' status was reaffirmed. As the state and its institutions grew stronger, new ideas emerged such as the necessity to protect the military and its troops from airborne surveillance and actions. Following the example of contemporary militaries of that era, officers and specialists were trained and educated in Russia and the West.

The first successful flight on a device heavier than the air with its own motor called airplane or avion was carried out by the Wright brothers ${ }^{1}$ on 17 December 1903 in the United States of America. That is the beginning of the era of airplanes, which have first gradually and during the World War I completely pushed aside balloons and blimps. Namely, before airplanes, during a period of over 100 years, balloons were developed (the first one flew in 1783) and a little later huge airships - blimps, the oldest of which was Zeppelin ${ }^{2}$. A means of transport by the air was a great novelty, and also great challenge in terms of its potential use for the military purposes. In less than a decade from the appearance of airplane as a new flying device, its military use and development into one of the most powerful weapons the man has ever made began.

All that happened in the field of aviation at the beginning of the $20^{\text {th }}$ century had an echo and a lasting effect in our region, as well. The enthusiasm and fascination with this revolutionary novelty was especially apparent on the pages of the newspapers, which followed with great attention the successes and failures of the first aviators, encouraging people with a daring spirit to experience aviation themselves.

Right at the beginning of the aviation, a strong aviation movement developed in Serbia manifested through flight demonstrations by the most well - known pioneer airmen of that time. From 1909 until the beginning of World War I, a very active group of young enthusiasts functioned in Serbia, initially building flying models and organizing competitions, and from 1910 onwards Branislav Nušić, Dragoš Aleksić and Deroko brothers built gliders, too.

Among the Serbian aviation pioneers are Vladimir Aleksić, PhD, Ivan Sarić and Mihajlo Merćep. On $17^{\text {th }}$ October 1909 Vladimir Aleksić, PhD, from Pančevo performed a trial flight with a double winged glider set in motion using a tightened rubber cord. On that occasion he reached the height of 15 meters, but the glider collapsed because of strong winds and

\footnotetext{
11 December 1903 was entered into the history of aviation as the day when the first successful flight on an airplane with a combustion motor was carried out by Orville and Wilbur Wright near a small town Kitty Hawk, North Carolina. The fourth and the last flight that day lasted 59 seconds covering the distance of 259.7 meters. The Wright brothers continued with their endeavors despite the troubles which they experienced, establishing the pilot school in the process. When on 9 September 1908 their airplane managed to fly an hour and two minutes, even the last doubts disappeared. The era of accelerated development of aviation began. Airplanes soon found their use in air traffic. When on 23 October 1911 Italian captain Carlo Piazza flying on his Bleriot airplane carried out surveillance of Turkish and Arabic troops in the Italian-Turkish conflict of 1911/12 the use of airplane for the military purposes began. The first military airplane flight sets in motion the speedy development of a new weapon, which shall entirely change the modern strategy and tactics in the $20^{\text {th }}$ and $21^{\text {st }}$ centuries.

${ }^{2}$ Named after famous German constructor Ferdinand Zeppelin.
} 
insufficient stability. Aleksić suffered light injuries, but soon he continued with his experiment planning to install a motor into the glider, but he was prevented by premature death. The man from Subotica, Ivan Sarić, had his first contact with airplanes in June 1909 at the airfield near Paris, where he met Louis Bleriot. The airplanes fascinated him and he secretly took a photo of Bleriot's monoplane, collected literature and, having received a friend's promise to give him a motor, rushed to Subotica, where he built his own airplane. In June and July 1910, he performed his first flights, while on 16 October 1910 he had a public flight with a new $50 \mathrm{HP}$ motor before a crowd of 7,000 people. The full-scale five-cylinder motor from his airplane is kept today on display in the Museum of Aviation in Surčin.

Mihailo Merćep spent his childhood in Serbia at his father's estate, awarded to him by Prince Mihajlo for his services during the defense of Belgrade in 1862. Later on, he attended school in America, where he attentively followed the developments in the field of aviation, the achievements of the Wright brothers, Henri Farman and others. He collected a considerable amount of notes, plans and useful literature, and in 1909 he started to construct an airplane. Together with a Slovenian Edvard Rusijan, he came to Belgrade to show his airplane and perform a public flight. Rusijan took off from the field in the Lower Town near Kalemegdan, flew around the railroad bridge over the Sava River and landed. However, while the enthusiastic audience was awaiting the landing, a strong wind blew and tore the airplane wings apart, causing Rusijaan to crash and die. Branislav Nušić, a writer, gave a farewell speech in front of Hotel Moscow, and the funeral turned into a great patriotic manifestation.

Mihajlo Merćep was a Serb from Dubrovnik who lived in Zagreb, where he had a shop for manufacturing airplanes. In May 1912 he delivered to the Serbian patriots from Belgrade a commissioned airplane "Merćep-komitski", which was used in combat during the campaign for liberation of the southern Serbian regions. When World War I broke out, the Austro-Hungarian authorities destroyed Merćep's shop, and treated him inhumanely for the sole reason of being a Serb.

Several foreign pilots flew in Belgrade at that time. The Czech Rudolph Simon had a few flights on Banjica, but his biplane was wracked during one of the flights. The Russian pilot Boris Maslenikov had over 20 flights in December 1911 and January 1912 using the opportunity to fly member of the Royal family, officers and citizens in his forman. The Czech Jan Cermak and Italian Gianni Widmer further strengthen public belief in the validity of airplane as a new transportation and military device.

The press pointed out the significance of aviation in the future wars and stressed the need to train personnel and acquire airplanes in timely fashion, and urged sending officers to attend professional training in France.

One of the best educated Serbian officers at the time, Colonel Miloš Vasić, in the capacity of the Minister of the Military, foreseeing the formation of aviation units, made a decision in 1900 to begin schooling aviation experts. In February 1900 the Serbian Ministry of the Military sent engineering captain Kosta Miletic to attend school in Russia, where he mastered handling free balloons and became familiar with the workings and organization of pigeon mail. Upon return to Serbia, Miletić made a proposal to create one balloon unit, but the proposal ended up in the archives because of insufficient interest of the superiors. Serbia, nevertheless, gained its first educated aviation officer.

The events of 1908/09 following the illegal annexation of Bosnia and Herzegovina demonstrated the need for modernization of the Serbian military, so two balloons were acquired, one free called Serbia, and one tied called Bosnia and Herzegovina, which had its unequivocal 
meaning. Due to the lack of financing, a Hydrogen station was not built, so the functioning of the Balloon unit was interrupted, and the balloons were stored into warehouses in Niš. The operation of this unit was reestablished before the beginning of the First Balkan War. Serious preparations for pilot education began only after it became clear that the war with Turkey was imminent. Three officers and three non-commissioned officers were sent in May 1912 to attend school in France. Upon the completion of officers training, the Serbian government commissioned and brought in France eight modern airplanes: three Farmans, three Blériots and two Deperdussins. Along with the airplanes, mountable hangars, necessary instruments and spare parts were delivered, too, and additionally, three cameras for photo surveillance were purchased, as well. The airplanes were the most sophisticated ones that France had at its disposal. In October 1912, at the beginning of the First Balkan War, two Turkish REP type K airplanes were captured, while two Dux airplanes were received from Russia as a donation. Thus, Serbia had 12 airplanes in 1912, which was a considerable number at the time. As additional help to our pilots, four volunteers (three pilots and one mechanic) arrived from France and two pilots from Russia.

The developments on the front, and already completed material, technical, organizational and personnel preparations, ultimately resulted in implementing the decision on establishing the Serbian Air Force. The order of the Minister of the Military Radomir Putnik of December $24^{\text {th }}$, 1912 established the formation of the Air Force Command, the first Air Force unit of the Serbian Military consisting of: Airplane section, Balloon section, Hydrogen plant, and Pigeon mail.

Even though being a part of the Corps of Engineers, given the significance in the actual situation, the Air Force Command was directly subordinated to the Supreme Command of the Serbian Armed Forces. Major Kosta Miletic ${ }^{3}$ was named its Commander. It is apparent from the structure of the Air Force Command that there were no indications about formation of any instruments for the surveillance of the air space.

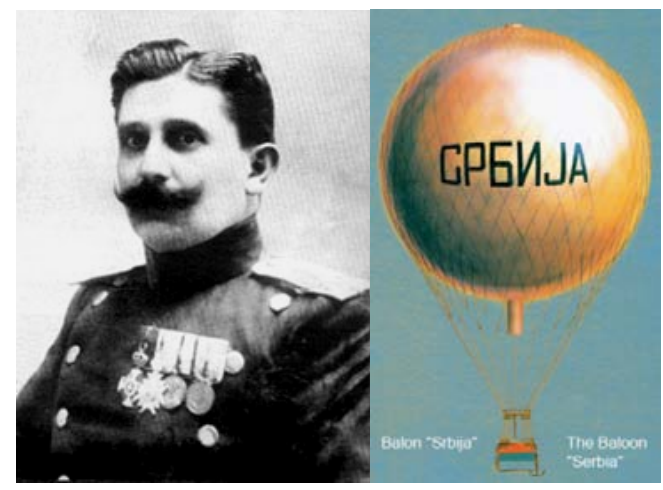

Figure 1 - Captain Kosta Miletić

\footnotetext{
${ }^{3}$ Captain Kosta Miletić attended the Technical Aeronautics School in Russia from 14 February 1901 to 12 November 1902. He was trained to be a pilot of tied and free balloons and for handling pigeon mail. Upon his return to the country, he worked on the practical establishment and organization of the pigeon mail, the purchase of the first balloons and the formation of the balloon department. He flew the first balloon, which was named "Serbia" immediately after the purchase on 19 April 1909. It was the first flight of the Serbian military aircraft with Serbian emblems. After the outbreak of the First Balkan War, he participated in the Kumanovo battle, as a battalion commander. He was promoted to the rank of major due to his courage. Upon the establishment of the airborne command he was appointed its commander and remained the head of the Serbian aviation until 1916.
} 
That was completely understandable because in the First Balkan War only the Serbian military airplanes took part, and the danger to our forces from airborne activities was not still apparent. The Balkan wars witness a rather widespread use of the Serbian aviation, especially for air surveillance, where the Serbian Air Force carried out 21 surveillance missions. During the siege of Skadar, from February to April 1913, surveillance missions were conducted daily, while in March, the Turkish positions were bombed using bombs and hand grenades loaded in a Blériot. In February 1913, the Littoral Airplane Unit was formed, which carried out combat missions above Turkish positions. By performing combat aerial operations in the First Balkan War, Serbia became one of the first five nations in the world to use aviation for war purposes. The bombing near Skadar was the first airborne bombing on the European soil. The combat sorties of the Serbian Air Force in the First and the Second Balkan Wars were observed by the military envoys from France, the USA, England and Spain and, based on that experience, innovated doctrines on the use of their aviation in war.

Right after the establishment of the Air Force Command, keeping in mind the beginning of the ceasefire on the battlefield, additional training, practice and preparation of pilots for combat duties were organized. Taking into account that foreign airplanes frequently flew over the Serbian territory, while Austria-Hungary banned Serbian, Russian and Italian airplanes from flying over its territory, on March $3^{\text {rd }}, 1913$ the Serbian government issued the Decree on Traffic by Devices Moving through the Air.

The decree established the legal basis for the sanctions that the Serbian authorities could use against the foreign (primarily Austro-Hungarian) airplanes and pilots, who would cross the state borders without authorization. The decree is the first legal document on the air traffic published in Serbia, and among the first in the world. This document reflects the necessity of controlling the airspace, not only at the time of war, but in peacetime, as well, and clearly indicates the need to establish an agency for surveillance and control of the airspace during peace and war.

In the Second Balkan War, the Serbian Air Force, in addition to airplanes, began to use balloons, as the hydrogen plant was operating. The first experiences in the use of balloons and airplanes were gained during the Balkan wars. Some shortcomings in organization, command and utilization were identified. However, technical problems, insolvable at the time due to the fact that the aviation was still in its infant stage, resulted in the lack of understanding and resistance toward a wider use of aviation for the military purpose.

\section{Use of Aviation in World War I in Our Theater of War and Organization of Air Defence}

After the Balkan wars, while the Air Forces of Austria-Hungary undertook comprehensive preparations for war, the Serbian Air Force was, after the great efforts and losses, completely inactive. Before the start of World War I, the Serbian Air Force had four airplanes and two balloons at its disposal. The aircraft were in poor condition and 
the pilots were out of practice. Upon the mobilization of 25 June 1914, the Airplane squadron in Niš was ready in seven days, and the Balloon section in twelve days. Aware of poor conditions in the Air Force, the Ministry of the Military and the Government undertook urgent measures to acquire airplanes and obtain experienced pilots in the allied countries, France ${ }^{4}$ and Russia. However, the acquisition process progressed very slowly because the aviation capacities of those countries were engaged to meet their own needs. Thus, the Serbian military had to rely on its own modest Air Force potential during the first nine months.

According to the initial concept of the Supreme Command of the Serbian Army, the aviation was supposed to provide aerial surveillance of the front facing AustriaHungary. Due to the limited capacity, the emphasis was put on the Drina River in the zone of the Third Serbian Army. For that purpose, the Air Force Command was relocated from Niš to Valjevo and subordinated to the Command of the Third Army. The surveillance flights carried out during this period had great significance for the overall actions of the Serbian Army. The information obtained through the aerial surveillance revealed with certainty that the main attack of the Austro-Hungarian Forces would take place across the lower course of the Drina River. The surveillance flights of the Serbian aviation ${ }^{5}$ contributed greatly to the magnificent victories of the Serbian Army on Cer and Kolubara.

In the initial phases of World War I Austro-Hungarian Air Force established the absolute dominance in the air, which enabled it to survey the territory in depth and to bomb Serbian positions and even towns. After the great successes of the Serbian Army toward the end of 1914 and the liberation of Belgrade on December $15^{\text {th }}$ of the same year, measures were undertaken, with the French assistance, to strengthen the Serbian Air Force. The French government sent a complete airplane escadrille, staffed with the best pilots, surveyors, mechanics, photographers and other specialists. The escadrille boarded a ship on 3 March 1915 and departed from Marseille to Thessaloniki, then further to Niš, where it arrived on 15 March 1915. The flying units continued to Belgrade, while the technical section went to Smederevska Palanka.

The French escadrille was subordinated to the Supreme Command of the Serbian Military and it was in charge of section of the front from Smederevo to Loznica, with the outer surveillance zone to the line: Alibunar - Slankamen - Novi Sad - Bačka Palanka Bijeljina - Loznica. Serbian airplane escadrille was stationed at the airport near Požarevac and was in charge of the front section from Smederevo to Golubac, with the outer surveillance zone to the line: Petrovo Selo - Vršac - Bela Crkva - Golubac.

\footnotetext{
${ }^{4}$ The French escadrille had 99 men: nine officers, 18 non-commissioned officers and 72 corporals and soldiers. It consisted of 8 pilots, 5 reconnaissance officers, one doctor, 16 mechanics and 16 drivers. The escadrille was equipped for longer operations. It had 12 new airplanes type Maurice Farman MF, 11 designed for multiple use, and 6 were armed with machine guns. The airplanes were equipped with a radio station, which enabled the correction of artillery fire, target pointer, and an aerial photographic camera. In addition to the aircraft, the escadrille had 10 prefabricated fabric hangars, two trucks, two passenger cars, spare aircraft engines, a portable mechanical and carpentry workshop with a large amount of materials. The airplanes were made of wood and glued fabric. The commander was Major Roger Vitre.

${ }^{5}$ Surveying the Drina River crossings.
} 


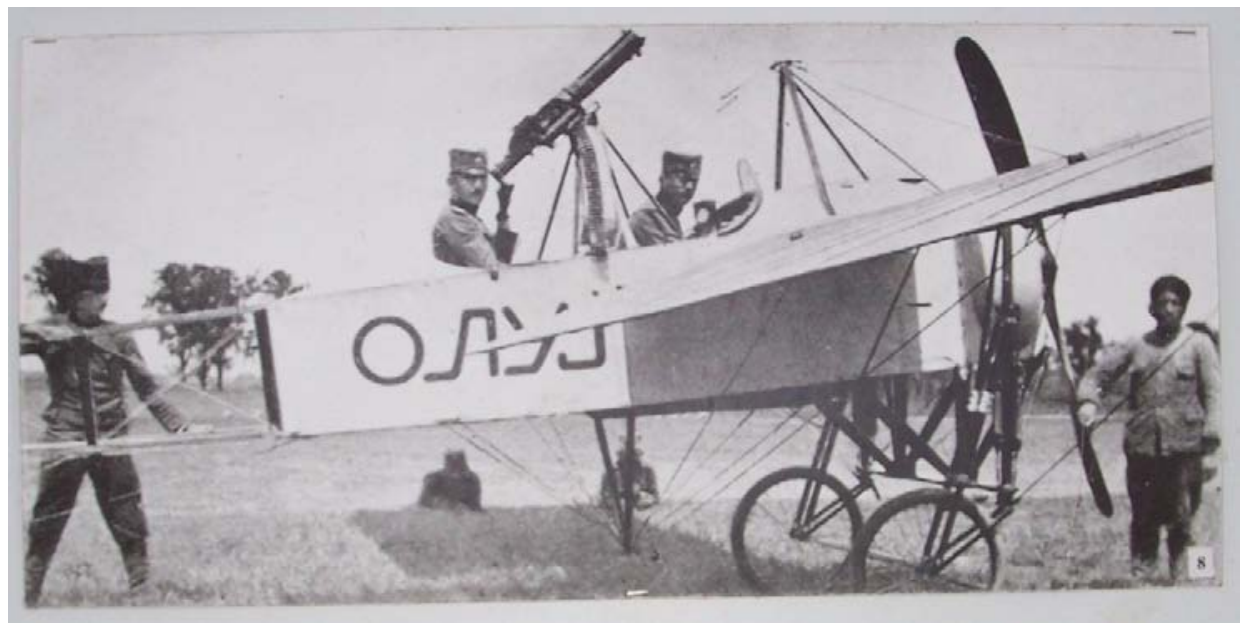

Figure 2 - The first Sebian armed airplane „Oluj“ (Storm) 1915

In April 1915 Serbian airplane squadron obtained two Blériot airplanes from the French. One of the two had a built-in infantry machine gun and that was the first Serbian armed airplane named Oluj (Storm). The tasks assigned to the Air Force units by the Supreme Command of the Serbian Military were: to survey the enemy territory from the air with the aim of recording the distribution and the movement of the enemy troops, to act offensively against the Austro-Hungarian river vessels on the Danube River, to fight for the air superiority by engaging in combat against the enemy airplanes in the air and the air bases. to bomb the enemv infrastructure and troops. It can be noticed from the aforementioned tasks that there was a need for reconnaissance of the airspace ${ }^{6}$, not only in order to protect our troops from the air attacks, but also for the purpose of directing our airplanes against the enemy airplanes in the struggle for the air supremacy. According to the Serbian Supreme Command plans, continuous in-depth reconnaissance missions over the enemy territory were carried out, as well as photo recording of the front lines, and the bombing of the enemy air bases and river navy vessels on the Danube River. The air supremacy was already established with frequent air combat in the first half of 1915. However, in accordance with the development of the situation on the front, the activities of the enemy Air Force increased, so the Supreme Command of the Serbian military took steps to establish the system of anti-aircraft defence. Therefore, the camouflage of the units was improved, while the Military Technical Institute in Kragujevac modified several cannons for shooting air targets and trained the crews. Based on the proposal of the French pilots, surveillance of the airspace began in May in order to "suc-

\footnotetext{
${ }^{6}$ The order of the Drina Division on reporting on the appearance of enemy airplanes of 29 May 1915, addressed to the Commander of the Army Artillery Regiment, stated: According to the order of the Supreme Command, I order that in case of the enemy airplane crossing the borer, the division headquarters be reported as soon as possible on the time of their crossing of the border and direction of the flight, so that our French airplane command could take steps to pursue enemy airplanes in a timely manner.
} 
cessfully chase the enemy airplanes". The system of visual survey of the airspace was initially established according to the agreement between the French military pilots and the division commanders of the Serbian military.

\section{Establishment, Purpose, Tasks and Work Methods of the Airplane Signal Stations}

Based on the previous experience, the Supreme Command of the Serbian Military, by means of its order of 18 June 1915 initiated the formation of permanent airplane signal stations in the areas controlled by Drina second call division, Timok ${ }^{7}$ division and combined division. In such way, by organizing observation of the airspace as a basis, the system of anti-aircraft defense in the Serbian military started to be established.

The key elements of visual surveillance of the airspace were airplane signal stations. The primary purpose of airplane signal stations was to observe the appearance of enemy airplanes, to signal their presence, and to indicate the direction of their movement for the benefit of the Serbian military pilots. The need for establishing airplane signal stations arose from the necessity to alarm, lift and direct the Serbian military airplanes in timely fashion, by tracing the direction of flight of the enemy planes ${ }^{8}$.

As the enemy airplanes carried out surveillance and offensive combat activities, the signal stations had a prominent role in alarming the Serbian army troops too, enabling them to undertake measures to counter enemy surveillance and offensive actions from the air. By establishing the anti-aircraft artillery units in the Serbian army, the signal stations gained even greater significance, resulting in increasing their number and types.

An airplane signal station was not a standard formation, and the personnel and equipment were allocated according to the order of division commander, drawn from certain units and according to the set criteria. Each airplane signal station had its commander, three full-time signal soldiers engaged in stretching the signal sheet, and two telephone operators. From such division commander's order, as well as from his other orders, it is apparent that great attention was paid to the selection of a station commander, who had to have both general and military education. Depending on the location of a station within a given combat disposition, two cavalry messengers would be allocated if needed, for the purpose of maintaining communication with the closest telephone station or command in charge.

A signal station had to have the following equipment:

1. Two white signal sheets 5 meters long and 1 meter wide. At each end, along the narrow sides of the sheet, two laths were attached to facilitate handling during the placement;

2. A compass for indicating the direction;

3. Parts of topographic map of the area, scale 1:75.000. Map was supposed to be used by the station commander. Station commander was supposed to have a wristwatch.

\footnotetext{
${ }^{7}$ The order of the commander of Timok division for determining the composition of the signal stations specifies the strength of the station, one reliable and reasonable officer, a student (commander of the station), who should be familiar with reading map, then four soldiers and telephone operators.

${ }^{8}$ "The most successful pursuit of the enemy airplanes possible“
} 
4. Binoculars - if possible;

5. Tools for sending information on the passing of the enemy airplanes to the regiment command (telephone, tool for telegram writing);

6. Set of information for correct distinction between its own and enemy airplanes (airplane pictures and similar);

7. A listening device - introduced as part of equipment of certain signal stations.

The stations were set up in such a way that the sheet for marking the direction of the airplane movement could be seen not only when the airplanes would be flying directly above, but also to the side. Generally, when choosing location for the station, a wooded area should be avoided.

At the location chosen for setting up the signal station, the area for positioning the signal sheet should be cleared of bushes, weeds, etc. At the location cleared in such a way, 1.5 meter or so high post should be set, and a circular area, 5 to 7 meters in radius should be grooved. Within that circle, using compass and rope, spreading out from the post, directions indicating east, west, north, south, northeast, northwest, southeast and southwest should be marked.

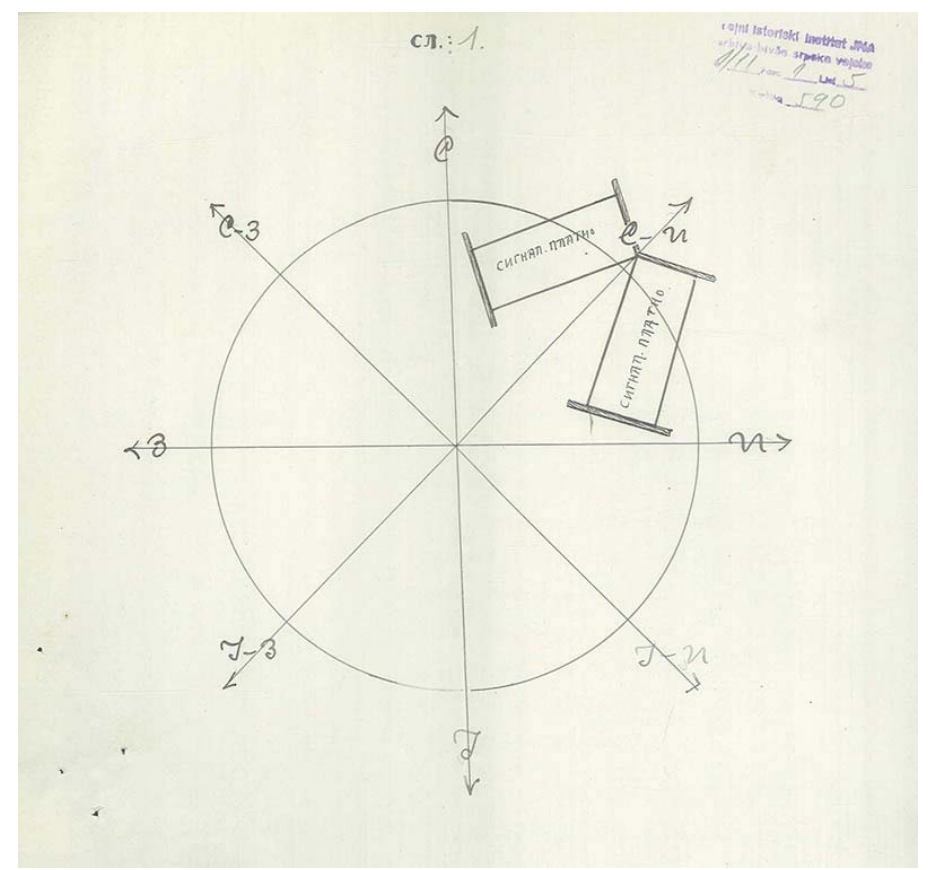

Figure 3 - Positioning sheets for indicating airplane flight - from the order of the commander of Timok division

At a distance of eight meters from the center of the circle, the marked directions east, west, north, south, northeast, northwest, etc. were to be additionally marked by eight wooden posts and plates denoting each direction. The plates with those marks need to be oriented 
toward the pivot, whereas the posts should be one meter high above the ground. While positioning the signal sheet, care should be taken to indicate the latest direction of the movement of the enemy airplane, and not the direction of a circular flight. The signal is created simply by setting the sheets on the ground to create an arrow in the direction of the airplane movement.

Airplane signal station should, if possible, be connected to its command by telephone while, in absence of such a connection, infantry of cavalry rallies are used. The division command is being informed (via division telephone station) about the appearance of enemy airplanes, which then informs the Army Command. The laid sheets remain on the ground until its own airplanes fly by, i.e. a half an hour to an hour at least. The information is sent in a written form if rallies are used, otherwise via telephone.

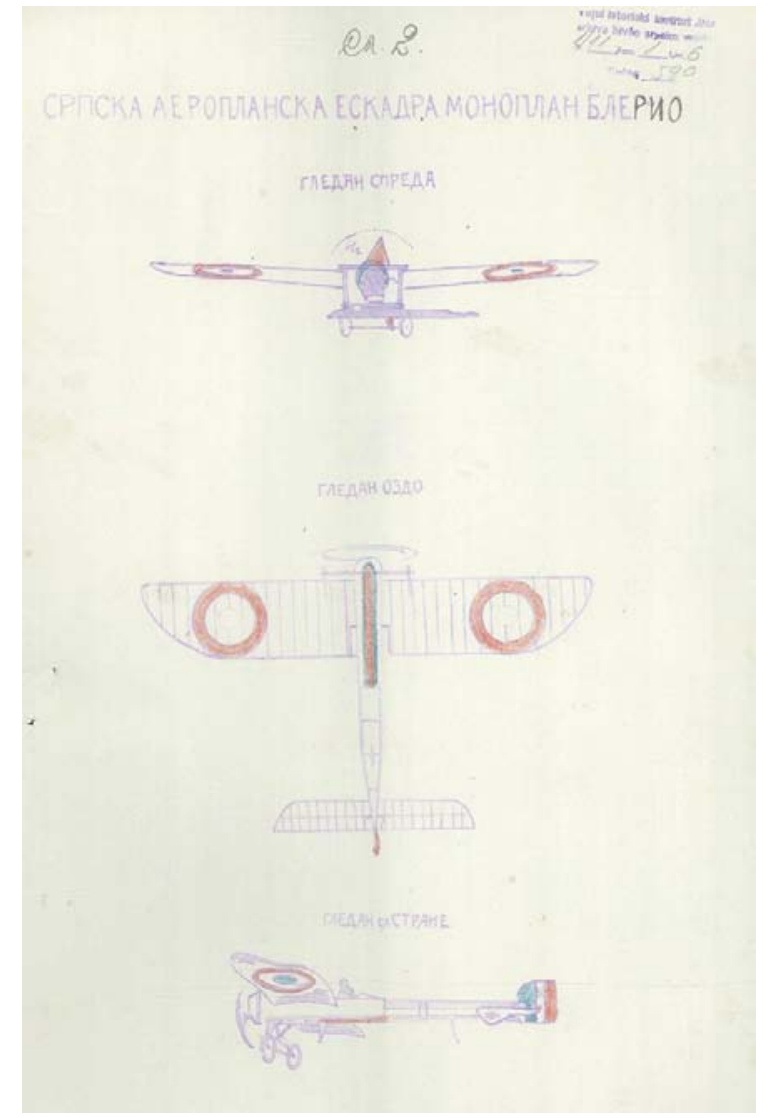

Figure 4 - Markings of our and enemy airplanes given in orders by means of pictures and a corresponding text ${ }^{9}$

\footnotetext{
${ }^{9}$ Our airplanes are of a "Monoplane" type, with simple wings, which have circular tricolors on the bottom, while the front of the body is painted in red and blue, with two winglets at the tail painted in tricolor. The enemy airplanes
} 
Airplanes of that time were mainly constructed out of wood and canvas, and metal to a lesser degree. The flight speeds were around 100 kilometers per hour.

The chart provides typical examples of the airplanes of the period and their basic characteristics:

\begin{tabular}{|l|l|c|l|}
\hline \multicolumn{1}{|c|}{ Airplane type } & \multicolumn{1}{c|}{ Purpose } & Crew & \multicolumn{1}{c|}{ Speed } \\
\hline R.E.P. type K & surveillance & 2 & $115 \mathrm{~km} / \mathrm{h}$ \\
\hline Dux & surveillance & 2 & $86 \mathrm{~km} / \mathrm{h}$ \\
\hline Henri Farman 20 & surveillance & 2 & $105 \mathrm{~km} / \mathrm{h}$ \\
\hline Farman F 40 & surveillance & 2 & $135 \mathrm{~km} / \mathrm{h}$ \\
\hline Bleriot XI-2A & surveillance & 2 & $120 \mathrm{~km} / \mathrm{h}$ \\
\hline Deperdussin & surveillance & 2 & $115 \mathrm{~km} / \mathrm{h}$ \\
\hline Nieuport XI C.1 & fighter & 1 & $152 \mathrm{~km} / \mathrm{h}$ \\
\hline Dorand AR.2 A2 & bomber & 2 & $153 \mathrm{~km} / \mathrm{h}$ \\
\hline Breguet XIV B.2 & bomber & 2 & $176 \mathrm{~km} / \mathrm{h}$ \\
\hline
\end{tabular}

If the signal station had no telephone connection with its command, two cavalry messengers would be allocated for the purpose of maintaining communication with the closest telephone station. Both at the signal and the telephone stations, one of the horsemen had always to be ready to depart to the telephone station or vice versa.

Upon appearance of the enemy airplane, the procedure was the following: when the station observer on duty notices a flying airplane, he immediately informs the station commander, who establishes whether the plane was allied or enemy (performs identification). In case it is an enemy plane, the commander defines the direction of the flight and orders placement of the sheets accordingly, to show to his airplanes the direction to pursue. Immediately after that, via telephone, he informs the superior command's telephone station or the designated one, which conveys the information to the chief of staff or the officer on duty, so that the division and army commands and adjacent troops could be informed.

The division station records the time, place and the direction of flight of the enemy airplanes, and informs other signal stations. Upon receiving the mentioned information, the commanders of other signal stations undertake measures to detect the enemy airplanes themselves and to position the signal sheets. The signal sheets should be positioned in the mentioned direction, even when the airplanes cannot be observed from that particular station, as our pilots could possibly see only the signals from that station. Such procedure applies even when the division telephone station receives the information on the movement of the enemy airplanes from some other unit or adjacent troops. When there is no telephone connection with the division telephone station, the written report is sent via cavalry messenger to the subordinate telephone station, and the rest of the procedure is the same. Alarming and lifting of our own airplanes takes place according to the orders and instructions issued by the army command and division command in real time.

The division commander orders a regiment commander to choose one officer in the rank of captain-lieutenant, to pick locations for placing the signal stations, handle their setting up, train the crew, pay visits and control their operation. An officer-supervisor is

are of a type "Biplane", with double wings, which have crosses at the outer edges of the upper wings, while all the wings edges are painted in red. There are two swallow tail wings at the airplane wing also painted in red. 
designated to control the operations of all signal stations, and he pays a visit to each of them at least once a week. The signal station commander is responsible for the performance of the station, he reports to the supervisor during his visit, informing him about everything that happened at the station. There is always, day and night, one observer on duty, who surveys the skies for airplane movement. Crew lodging takes place in a tent near the signal circle. All the signal units are supplied by the regiments they belong to. Airplane signal stations are organized either as permanent or movable. The minimal distance between them should not be less than seven kilometers. During movements and operations the stations are to function as described.

By means of using airplane signal stations, a system of observation and reporting the activities in the airspace was established. That system functioned in the territory of the Kingdom of Serbia until autumn 1915 when the Air Force of Austria-Hungary and Germany achieved air dominance. A large number of Serbian airplanes was lost or not combat ready. French personnel, who had come before the war to aid the Serbian aviation went back to their country on 28 December. During the retreat over Albania our remaining aviation performed surveillance for the Supreme Command, medical and other transport; airplane signal stations network was not developed, and surveillance of airspace for the purpose of protective measures was carried out by visual observers organized by separate units for their own needs.

\section{Use of Aviation and Airplane Signal Stations on the Thessaloniki Front}

During the Serbian Golgotha - the retreat through Albania, the Serbian Air Force retreated to Corfu along with the Serbian Army. In January 1916, the Serbian Government signed an agreement, which provisioned France supplying the Serbian military with five airplane squadrons and the accompanying units. The decision was materialized when the Serbian Army was transported from Corfu to the posts near Thessaloniki. Based on the agreement and the Allied decision of 30 May 1916, the French East Army Aviation (seven squadrons) and the Serbian Army Aviation (five squadrons) were established. The three Serbian Armies received the support of one squadron each, while the remaining two were under direct orders of the Serbian Supreme Military Command. The units were directly involved in the surveillance and reporting system through the reestablished system of airplane signal stations and by visual observation within the units themselves. Their development was primarily geared towards protection of the Thessaloniki port and the forces distributed around it. However, the enemy aviation was very active along the full length of the Salonica Front. The enemy penetrated deep into our territory in swarms, bombing our ammunition depots, hospitals, camps and other important targets. The enemy tactics was precisely defined, thus insuring success. In order to prevent the actions of the enemy aviation, the Command of the allied forces on the Salonica Front issued on 2 March 1917 instruction for the use of allied aviation. The instruction specifies the methods of coordinated functioning and greater unity of action by the French, British, Serbian and Italian aviation. The future actions were envisaged as joint activities under unified command. 
The instructions regulated the principles of aviation usage, ordering active defensive measures and transitioning into offensive. That includes not only combat during the interception of the enemy airplanes, but pursuing when retreating and attacking the enemy airstrips. The active defensive required perfect organization of the information network i.e. system of airspace surveillance. ${ }^{10}$

Accordingly, the first reports of the oncoming enemy aircraft were to originate from the front lines with the goal of timely take-off of our airplanes, followed by continued reporting from the area behind the front lines for the purpose of chasing the enemy away. It was necessary to organize the network of stations in the background, which has not always been done. The attached excerpt from the order of the Third Army testifies to that. For good functioning of the signal station network over such depth, in addition to the connections via telephone stations, radio-telegraph connections were introduced. Radio-telegraph connections were organized due to the need to correct the artillery fire.

The aviation-radio service was also introduced for the purpose of correcting the artillery fire. Radiotelegraphers were trained for both purposes. The use of radio telegraphy provided a new quality to the work of the visual surveillance stations. By the end of the war, a tightly coordinated activity between our airplanes and the visual signal stations was maintained. After the effective dismantlement of the Thessaloniki front, the signal surveillance stations were organized to a smaller degree as the activity of the enemy aviation became ever less present.

\section{Conclusion}

In the Balkan wars, the use of aviation in the Serbian military has not reached larger proportions, but the very knowledge that the Serbian military had aviation had a considerable effect on the morale of the military and the nation.

The Serbian military aviation came into existence at the beginning of the $20^{\text {th }}$ century, when the military glory of Serbia was created by the Field Marshal Radomir Putnik, Živojin Mišić, Stepa Stepanović and Petar Bojović, along with many clever and brave Serbian officers and soldiers. The Balkan wars were the first conflicts in which the aviation was used on the European soil. Aviation had already encompassed elements, which resulted in the establishment of current branches such as the Air Force and Air Force Defense. Serbia was among the first fifteen states in the world which had aviation, and among the first five using it in an actual war. During the first airplane and balloon activities the expectations were greater than the objective capabilities, primarily because of technical imperfections of airplanes, lack of reliability, meteorological conditions, yet non-existent usage of principles and tactics, as well as insufficient training and experience of pilots. Yet, aviation had a great effect on the morale of the Serbian troops, and it became apparent that aviation played an important role in conducting a war, hence a need for its more vigorous development. Until World War I, aviation was used primarily for surveillance and artillery preparations. However, by the end of 1918, the Serbian aviation, using

\footnotetext{
${ }^{10}$ The part of the order by the commander of the Third Army No. 7692 from 9 March 1918 aiming to eliminate shortcomings in organization of airplane signal stations. The order was issued based on the instruction of the commander of the allied forces at the Thessaloniki front, and it refers to the tactics of our aviation.
} 
its hard experience, carried out the duties of surveying the enemy territories for the purpose of detecting the distribution and the movement of the troops, combat actions against the war ships on the Danube, actions against the airborne enemy aircraft and their land bases, as well as bombing the enemy infrastructure and troops. Aviation carried out other missions too, including securing the dominance in the airspace, bombing, close air support and areal transport. Accelerated efforts were made to improve the flying characteristics of the airplanes (air dynamics and the motors), machine guns were mounted on the plain, which turned it into a very powerful and dangerous weapon.

The Serbian Air Force had, within its ranks, French airmen too, commander and squadron commanders. Such mixed Serbian-French units with five squadrons, through their sacrifices and efforts in 1916, and especially in 1917 and 1918, achieved extraordinary results and received well deserved recognition, as testified by the documents of the Supreme Command, section Commander, and Serbian Minister of the Military.

The fighting power of all armies in the preceding times was based on cooperation between artillery and infantry, which caused initial misunderstanding and opposition to introduction of airplanes into the arsenal. However, in all battles in which aviation participated, in addition to combat effects, it significantly affected the morale and fighting spirit of the ground forces. That especially holds true when talking about the main operation during the breakthrough of the Salonica Front. From the start, using aviation for military purposes required establishing airspace surveillance for the purpose of organizing anti - aircraft defense and air combat. The first airplane signal stations in the Serbian military were primarily organized for the needs of timely taking off and consequently directing our own airplanes to confront the enemy planes. In the Serbian military, three basic components of the Air Defense were formed: aviation, artillery units of anti-aircraft defense, and units for airspace surveillance. The coordinated development of all three components was a precondition for efficient anti - aircraft defense of the territory and the troops in certain periods. The Serbian aviation and airplane signal stations, through their activity, made a significant contribution to achieving a breakthrough of the Salonica Front. The Serbian airmen conducted around 3000 combat flights at the Salonica Front, participating in all major operations. At the end of the war the joint unit numbered over 60 modern airplanes. Within its ranks there were around 70 pilots, 40 scouts, and over 300 mechanics and other aviation specialists. These airplanes, equipment and personnel with immense experience formed the basis for creating military and civil aviation of the new south Slav state.

By means of organizing permanent observation stations and surveillance from the air, possible surprise actions by the enemy aviation were avoided. Our aviation's very presence in the air gave additional willpower and greatly increased faith in final victory and return home. Many members of the aviation units and the airplane signal stations were among those who gave their lives for freedom and honor of the fatherland. Those who survived, realizing the significance of aviation and airspace itself, continued to develop and strengthen the Air Force and Air Force Defense, and were always the first to defend the countries' honor and freedom.

In its efforts to maintain freedom and independence in such a delicate region, Serbia has often been, in the course of its turbulent history, in a position of not being able to avoid events which, by the rule, have brought wars and destruction. In such circumstances, the armed forces in general, and more recently aviation too, have been of great 
importance. In 1893 ideas on the use of aviation were considered, and in 1912 the Kingdom of Serbia established its aviation, which greatly contributed to the victories in the Balkan Wars and World War I.

The bright pages of our turbulent history have always been written in blood of our soldiers, amongst them the aviators too, who in the ensuing events of World War II and towards the end of the previous century gave birth to great heroes as well, such as pilots Života Đurić, Zoran Radosavljević and Milenko Pavlović. Even though they knew they were pursuing an impossible mission, they have not yielded. On the wings of their youth, not worrying for their lives, they flew directly into a legend, leaving all of us with a sense of pride.

\section{Literature}

[1] Rajic Bošković, retired colonel: Sky at the palm, century of area surveillance and reporting, Press the Official Gazette, 2017.

[2] Zlatomir Grujić: Ninety years of Air Force and Anti Aircraft Defense, New Gazette 6/2002.

[3] Zlatomir Grujić: Ninety years of Air Force and Anti Aircraft Defense, Military 34/2002

[4] Group of authors: Serbian Aviatics 1912-1918, Belgrade, 2000.

[5] Vladeta D. Vojinović: Serbian Aviation at the Thessaloniki front 1916-1918, Belgrade, 2000.

[6] Vladeta D. Vojinović: Serbian Aviation 1916-1917, per book titled "Memorandum no.1", Belgrade, 2000.

[7] Zlatomir Grujić: Serbian and Yugoslav Aviation 1901-1994, NIU Military, Belgrade 1997.

[8] Čedomir Janić: Eight decades of Serbian Aviation," Military", Belgrade,1992.

[9] Group of authors: Initiators of Aviation, Illustrated History of Aviation, IZO Vuk Karadžić, Belgrade 1988. 1987.

[10] Group of authors: Sky Warriors, Illustrated History of Aviation, IZO Vuk Karadžić, Belgrade

[11] Đorđe Milinović: From Icarus to Mars, Belgrade, 1980.

[12] Group of authors: Guardians of Sky, The AF and AAD Command, Belgrade 1977.

[13] Military-Historic Institute of YPA, Yugoslav Volunteer Corpus in Russia1914-1918, VIZ "Vojno Delo", 1954.

[14] Savo Mikić: History of Yugoslav Aviation, Belgrade, 1933. 